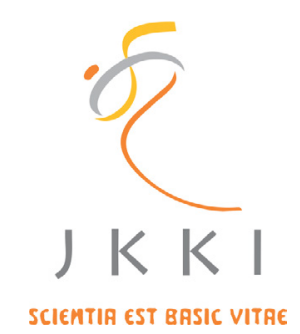

Jurnal Kedokteran dan Kesehatan Indonesia

Indonesian Journal of Medicine and Health

Journal homepage : www.journal.uii.ac.id/index.php/jkki

\title{
Cardenolides source and therapeutic effects
}

\author{
Zahia Kabouche*1 \\ ${ }^{1}$ Université des frères Mentouri-Constantine, Départment de chimie, Laboratoire d'Obtention de Substances Théra- \\ peutiques (LOST), 25000 Constantine, Algeria
}

\begin{tabular}{|c|c|}
\hline \multicolumn{2}{|c|}{ EDITORIAL } \\
\hline ARTICLE INFO & 7 he cardenolides and bufadienolides are the cardioactive glycosides \\
\hline $\begin{array}{l}\text { *Corresponding author: } \\
\text { zahiakabouche@umc.edu.dz }\end{array}$ & $\begin{array}{l}1 \text { in mammals. Their structures are different where the cardenolides } \\
\text { are } \mathrm{C}_{23} \text { steroids having an } \alpha, \beta \text {-unsaturated } \gamma \text {-lactone (butenolide) ring, }\end{array}$ \\
\hline OI : 10.20885/JKKI.Vol8.Iss3.art1 & $\begin{array}{l}\text { six-membered lactone ( } \alpha \text {-pyrone or hexadienolide) ring. }{ }^{1} \text { Certain } \\
\text { bufadienolides possess antitumour activity. }\end{array}$ \\
\hline & $\begin{array}{l}\text { In their glycoside form, cardenolides have cardiac properties. The class } \\
\text { includes cardadienolides and cardatrienolides: digitoxin, acetyldigitoxins, } \\
\text { digitoxigenin, digoxigenin, digoxin, acetyldigoxins, medigoxin, cymarin, } \\
\text { neoconvalloside, ouabain, strophanthidin, strophanthins. Digitoxin is now } \\
\text { rarely used in current Western medical practice whereas digoxin is used } \\
\text { to treat atrial fibrillation, a heart rhythm disorder of the atria. Digoxin } \\
\text { and its derivatives (acetyl- and methyldigoxin) inhibit the Na/K-ATPase } \\
\text { to regulate heart contractions. }\end{array}$ \\
\hline
\end{tabular}

In plants, cardenolides appear to be confined to the Angiosperms. It found in Apocyanaceae (Asclepias, Pergularia, Calotropis), Nymphalidae (Danaus), Scrophulariaceae (Digitalis, Isoplexis), Ranunculaceae (Adonis) and Convallariaceae (Convallaria, Speirantha). Recently, we reported cardenolides from Salsola tetragona (Amaranthaceae). ${ }^{4}$ Oleandrin and oleandrigenin, found in Nerium oleander L., are used to treat cardiac abnormalities in Russian and Chines medicine. ${ }^{5}$ Unlike digoxin which is eliminated via the kidneys, tardigal is characterized by a longer half-life and by its elimination via the liver so it could be used in patients with poor or erratic kidney function. ${ }^{6}$ Cardenolides have also been reported to possess anti- cancer and anti- HIV properties. ${ }^{7-9}$

\section{REFERENCES}

1. Schoner W. Ouabain, a new steroid hormone of adrenal gland and hypothalamus. Experimental and Clinical Endocrinology \& Diabetes. 2008;108(7):449-54.

2. Yamagishi T, Haruna M, Yan XZ, Chang JJ, Lee KH. Antitumor agents, 110. Bryophyllin B, a novel potent cytotoxic bufadienolide from Bryophyllum pinnatum. Journal of Natural Products. 1998;52(5):1071-9.

3. Samuelsson G. Drugs of natural origin: A text book of pharmacognosy, 5th. Swedish Pharmaceutical Press, Stockholm; 2004.

4. Ghorab H, Khettaf A, Lehbili M, Kabouche A, Alabdul Magid M, Harakat D, et al. A new cardenolide and other compounds from Salsola tetragona Delile (Amaranthaceae). Natural Product Communications. 2017;12(1):3-5.

5. Hung KC. The pharmacology of Chinese Herbs. Boca Raton, FL, CRC Press, Inc; 1999.55 p. 
6. Reynolds JEF. Digoxin precautions. In Martindale. The Extra Pharmacopoeia, 30th Edition. The Pharmaceutical Press, London; 1993. 666-/ p.

7. Calderón-Montaño JM, Burgos-Morón E, Orta ML, Maldonado-Navas D, García-Domínguez I, López-Lázaro M. Evaluating the cancer therapeutic potential of cardiac glycosides. BioMed Research International. 2014;

8. Babula P, Masarik M, Adam V, Provaznik I, Kizek R. From Na+/K+-ATPase and cardiac glycosides to cytotoxicity and cancer treatment. Anticancer Agents in Medicine Chemistry. 2013;13:1069-87.

9. Singh S, Shenoy S, Nehete PN, Yang P, Nehete B, Fontenot D, et al. Nerium oleander derived cardiac glycoside oleandrin is a novel inhibitor of HIV infectivity. Fitoterapia. 2013;84:32-9. 